\title{
The combined effects of temperature and leaf wetness periods on soybean frogeye leaf spot intensity
}

\section{Interação entre temperatura e período de molhamento foliar na intensidade da mancha foliar olho-de-rã}

\author{
Juliane Nicolodi Camera ${ }^{1}$; Valéria Cecília Ghissi ${ }^{1}$; \\ Erlei Melo Reis ${ }^{2}$; Carolina Cardoso Deuner ${ }^{3 *}$
}

\begin{abstract}
The frogeye leaf spot, a disease caused by the fungus Cercospora sojina, affects soybean crops worldwide with enormous economic impact. In this study, we evaluated the combined effects of temperature and duration of leaf wetness periods on the intensity of frogeye leaf spot in soybean. Experiments were conducted in a growth chamber with cultivar Don Mario 7.0i at temperatures of 15, 20, 25, 30 and $35^{\circ} \mathrm{C}$ and leaf wetness periods of $12,24,36,48$ and 72 hours. The experimental design was completely randomized with five replications. When soybean plants were grown at $15^{\circ} \mathrm{C}$, affected leaflet area, number of lesions per leaflet and diameter of lesions could only be measured after 60 hours of leaf wetness. At the temperatures of 20 and $25^{\circ} \mathrm{C}$ this period was reduced to 24 hours of leaf wetness, at $30^{\circ} \mathrm{C}$, we found the need for 36 hours of leaf wetness and at a temperature of $35^{\circ} \mathrm{C}, 48$ hours. The optimal temperatures for disease development were $27^{\circ} \mathrm{C}$ for diameter and affected leaflet area and $28^{\circ} \mathrm{C}$ for number of lesions per leaflet with 72 hours of leaf wetness.
\end{abstract}

Key words: Cercospora sojina, Glycine max L.

\section{Resumo}

A cultura da soja apresenta grande importância mundialmente, entre as doenças que ocorrem nesta cultura está à mancha olho-de-rã (causada por Cercospora sojina). O objetivo deste trabalho foi avaliar a interação entre temperaturas e diferentes períodos de molhamento foliar na intensidade da mancha olho-de-rã em soja. O experimento foi conduzido em câmara de crescimento com a cultivar Don Mario 7.0i nas temperaturas de $15,20,25,30$ e $35^{\circ} \mathrm{C}$ e os períodos de molhamento foliar de $12,24,36,48$ e 72 horas. Cinco experimentos foram realizados, um para cada temperatura, $15,20,25,30$ e $35^{\circ} \mathrm{C}$ e os períodos de molhamento foliar 12, 24, 36, 48, 60 e 72 horas consistiram os tratamentos, o delineamento experimental foi inteiramente casualizado com cinco repetições. Quando as plantas foram submetidas à temperatura de $15^{\circ} \mathrm{C}$, severidade foliar, número de lesões por folíolo e diâmetro da lesão foram observados somente com 60 horas de molhamento foliar, para temperaturas de 20 e $25^{\circ} \mathrm{C}$ com 24 horas de molhamento foliar, para temperatura de $30^{\circ} \mathrm{C} \operatorname{com} 36$ horas de molhamento foliar e para temperatura de $35^{\circ} \mathrm{C}$ com 48 horas de molhamento foliar. A temperatura ótima estimada para o desenvolvimento da doença foi de $27^{\circ} \mathrm{C}$ para severidade e diâmetro de lesões e de $28^{\circ} \mathrm{C}$ para número de lesões por folíolo, com 72 horas de molhamento foliar.

Palavras-chave: Cercospora sojina, Glycine max L.

\footnotetext{
1 Discentes de Doutorado em Agronomia, PPAgro, Universidade de Passo Fundo, UPF, RS, Brasil. E-mail: ju_camera@yahoo. com.br; val_ghissi@hotmail.com

2 Pesquisador, OR Seeds, Passo Fundo, RS, Brasil. E-mail: erleireis@upf.br

3 Prof ${ }^{a}$ Graduação e Pós-Graduação em Agronomia, UPF, RS, Brasil. E-mail: carolinadeuner@upf.br

* Author for correspondence
} 


\section{Introduction}

Numerous diseases affect soybean crops [ Glycine $\max (\mathrm{L}$.) Merr.], among which, the frogeye leaf spot, caused by the fungus Cercospora sojina Hara, 1915, represents one of the most economically harmful. In the United States alone, estimated annual losses ranged from 183,868 to 345,148 metric tons between 2006 and 2009 (KOENNING; WRATHER, 2010).

In Brazil, a contaminated seed sample of the Bragg cultivar originated in the United States introduced the fungus in the state of Parana during the 1970/71 crop. No official data exists on the impact of frogeye leaf spot to soybean production since then. Nevertheless, frogeye leaf spot was the first disease to reach epidemic proportions in Southern Brazil (YORINORI; KLINGELFUSS, 2000), an event that marked the beginning of the soybean breeding program focused on genetic resistance to disease. Today, the use of resistant cultivars is the most efficient and cost effective means of controlling frogeye leaf spot, and is the main disease control measure adopted in Brazil (MIAN et al., 2009). This pathogen has not been associated with disease in any other crop or weed host (MIAN et al., 2008).

Disease development depends on the interaction among a susceptible plant, a virulent pathogen and a favorable environment. Host susceptibility and pathogen virulence remain relatively stable in the short term, whereas the environment may undergo frequent and important alterations even during a crop cycle. Environmental conditions mostly affect the onset of infection, potentially preventing it even when the host is susceptible and pathogens are present (BEDENDO; AMORIM, 2011). The presence of liquid water on leaf surfaces represents an important factor for the infectious process. The leaf wetness period refers to the period of time during which plant leaves remain moist (SUTTON et al., 1984). Dew water is essential for leaf wetness, especially during drier seasons. In parallel, temperature works as a catalyst agent for biological processes, thus, plants and pathogens require a minimal temperature to grow and maintain normal activity levels. In general, pathogens become more active in higher temperatures, when conditions are favorable, they more easily infect plants and cause disease (REIS; BRESOLIN, 2004). In summary, the infectious process of fungal diseases heavily depends on the interaction of leaf wetness periods and temperature.

In vitro studies indicated that the optimal temperature for conidia germination under continuous light was $22.4^{\circ} \mathrm{C}$ (CAMERA et al., 2013), whereas other work showed that mycelia growth and sporulation was optimized at $25^{\circ} \mathrm{C}$, with slower growth occurring at $32^{\circ} \mathrm{C}$ (CRUZ, 2008). Veiga (1973) reported that $48 \mathrm{~h}$ of wetness favors the onset of frogeye leaf spot. Data on disease progression under controlled and natural conditions have provided a critical tool for modeling epidemiological studies (DEL PONTE et al., 2006). Detailed knowledge of the conditions that favor infection and colonization allow for the development of management strategies that reduce pathogen establishment. Nevertheless, few studies have focused on in vivo effects of temperature and leaf wetness on the development of $C$. sojina. Therefore, the objective of this work was to determine the effects of temperature and duration of continuous periods of leaf wetness on frogeye leaf spot.

\section{Material and Methods}

Experiments were carried out in Conviron growth chambers model E7 in a completely randomized design. Five experiments were carried out, one for each temperature tested, $15,20,25,30$ and $35^{\circ} \mathrm{C}$ and, within each experiment, leaf wetness periods of 12, 24, 36, 48, 60 and 72 hours were tested. Each experiment was replicated five times.

We used isolate 25 of $C$. sojina provided by the Empresa Brasileira de Pesquisa Agropecuária (EMBRAPA Soja). This isolate came from soybean cultivar 'Cariri' from Balsas/MA, and fungal strain identification was performed through 
differential cultivar set reactions (YORINORI; KLINGELFUSS, 2000). We first conducted a monosporic isolation (ALFENAS; MAFIA, 2007) and later multiplied the pathogen on tomato extract-agar (HINE; ARAGAKI, 1963). We used an inoculum concentration of $40 \times 10^{3}$ conidia $\mathrm{mL}^{-1}$ measured with a Neubauer hematocytometer (ALFENAS; MAFIA, 2007).

Four plants of Don Mario 7.0i cultivar were sown in $2 \mathrm{~L}$ volume pots, and placed in a growth chamber at $25^{\circ} \mathrm{C}$ temperature and 12-hour photoperiod. Plants were inoculated when the second trifoliate leafs were totally developed by spraying the spore suspension to run-off. As an untreated control, five pots were sprayed with water and kept in a moist chamber that maintained continuous leaf wetness at different temperatures. At the end of each period, plants were dried with a fan and maintained in their respective temperature.

Disease components evaluated included affected leaflet area as a percentage of total leaflet area (DISTÉFANO et al., 2009); leaflet lesion number, which is the number of frogeye lesions on each leaflet; and leaflet lesion diameter; the average diameter of four lesions per leaflet measured with a digital caliper, evaluated fifteen days after inoculation. We evaluated the last fully expanded trefoil of each plant.

The mean values of affected leaflet area, diameter, and number of lesions per leaflet and temperature data were submitted to regression analysis. Temperature and leaf wetness data fit the quadratic polynomial curve $\mathrm{Y}=\mathrm{B} 1 \mathrm{X}^{2}-\mathrm{B} 2 \mathrm{X}$ $+\mathrm{B} 3$, where $\mathrm{Y}=$ the dependent variable (affected leaflet area, diameter, and number of lesions per leaflet), $\mathrm{X}=$ independent variable (temperature), B1 = estimated asymptote maximum $\mathrm{B} 2$ = parameter related to the initial inoculum and $\mathrm{B} 3=$ rate of disease progression. To describe the combined effect of temperature and leaf wetness duration on affected leaflet area, lesion number and lesion diameter, a function was fitted to the average of each variable by nonlinear regression using the STATISTICA software (StatSoft, Inc., 2001).

\section{Results and Discussion}

Both temperature and the duration of leaf wetness affected frogeye leaf spot intensity. Inoculated soybean plants kept at $15^{\circ} \mathrm{C}$ displayed affected leaflet area within $60 \mathrm{~h}$ of leaf wetness, whereas plants kept at 20 and $25^{\circ} \mathrm{C}$ were affected within $24 \mathrm{~h}$, those kept at $30^{\circ} \mathrm{C}$ within $36 \mathrm{~h}$, and the ones kept at $35^{\circ} \mathrm{C}$ within $48 \mathrm{~h}$. There were no disease symptoms within $12 \mathrm{~h}$ of leaf wetness regardless of temperature. The temperatures that maximized each variable were $27^{\circ} \mathrm{C}, 28^{\circ} \mathrm{C}$ and $27^{\circ} \mathrm{C}$ for affected leaflet area, number and diameter of lesions, respectively. Mean temperature for the maximization of these variables was $27.3^{\circ} \mathrm{C}$ (Figure 1). When correlating leaf wetness duration, lesion area, number and diameter, we observed that disease intensity increased as the duration of leaf wetness increased from $12 \mathrm{~h}$, when no disease was detected, to a 72-h maximum, following a quadratic polynomial model (Figure 2).

Combining the monomolecular-beta generalized function equations $[\mathrm{Z}=0.00731 *(\mathrm{~T} 15) * * 1.472 *($ $36 \mathrm{~T}) * * 0.5051)] *[1.298 / 1+6185.84 * \operatorname{EXP}(0.13$ $79 * \mathrm{HW})]$ where $\mathrm{T}=$ temperature, $\mathrm{HW}=$ hours of leaf wetness, for the temperature and leaf wetness duration, we generated surface response graphs for affected leaflet area (Figure 3A), and lesion number per leaflet (Figure 3B). The graph for lesion diameter (Figure 3C) was generated with the equation $\left[\mathrm{Z}=0.00731 *(\mathrm{~T}-15)^{* *} 1.472 *(36\right.$ $\mathrm{T}) * * 0.5051)]^{*}(1.298 * \operatorname{EXP}(6125.84 * \mathrm{HW})]$. We concluded that, regardless of the variable analyzed, disease intensity was highest at $27^{\circ} \mathrm{C}$ and with $70 \mathrm{~h}$ of leaf wetness.

Each pathogen-host system has its own critical weather period, few hours during which environmental conditions are favorable to infection, i.e. the infection site is continuously wet in a given temperature, so that spores germinate and parasites enter and become established in the host (REIS; WORDELL FILHO, 2004). 
Figure 1. Quadratic polynomial model of frogeye leaf spot variables versus temperature for each level of leaf wetness. (A) affected leaflet area (\%), (B) number of lesions per leaflet and (C) diameter of lesions per leaflet ( $\mathrm{mm}$ ) of frogeye leaf spot in soybean cultivar Mario 7.0i.

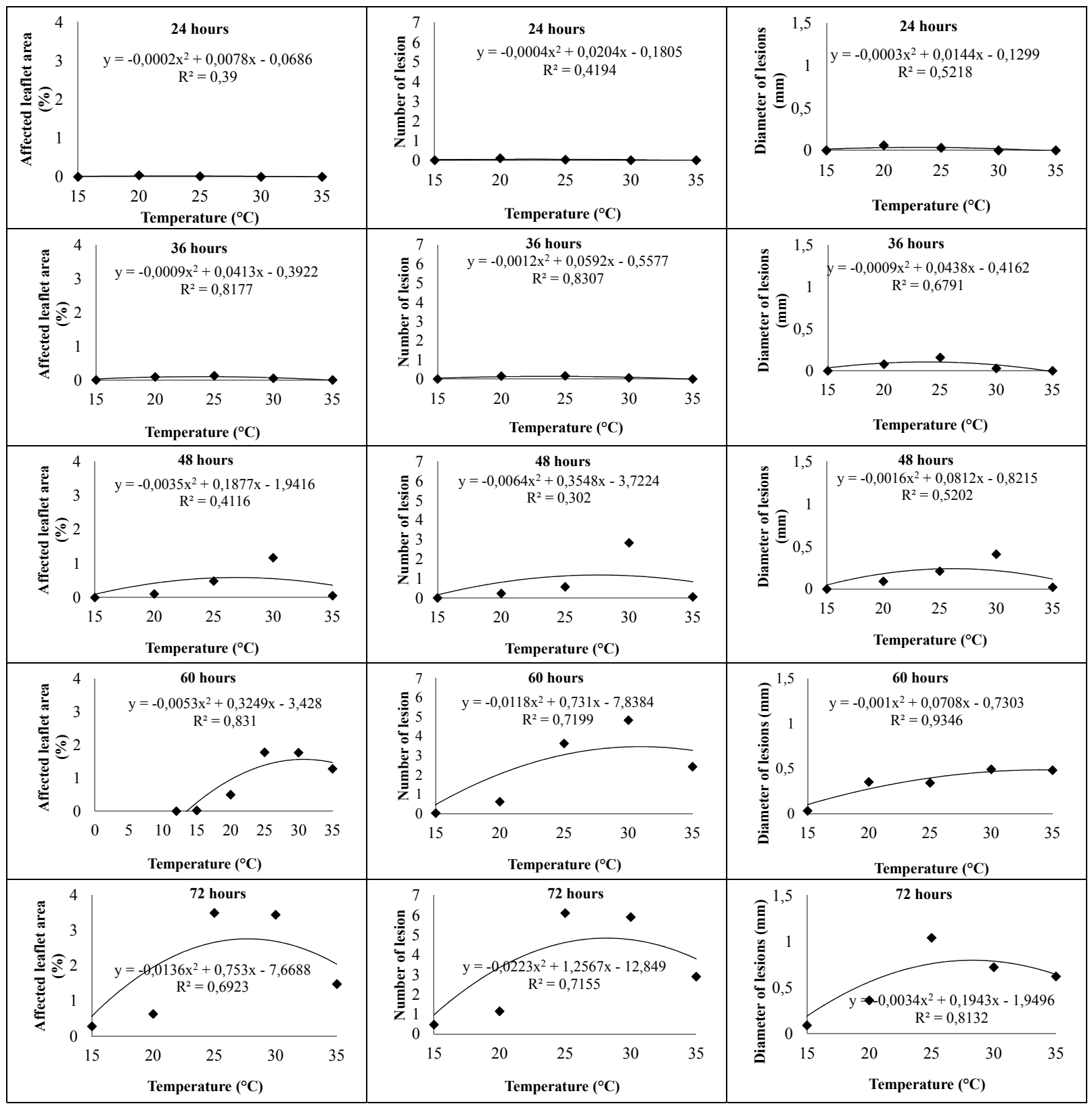


Figure 2. Quadratic polynomial model of frogeye leaf spot variables versus leaf wetness for each temperature level. (A) affected leaflet area (\%), (B) number of lesions per leaflet and (C) diameter of lesions per leaflet (mm) of frogeye leaf spot in soybean cultivar Mario 7.0i.

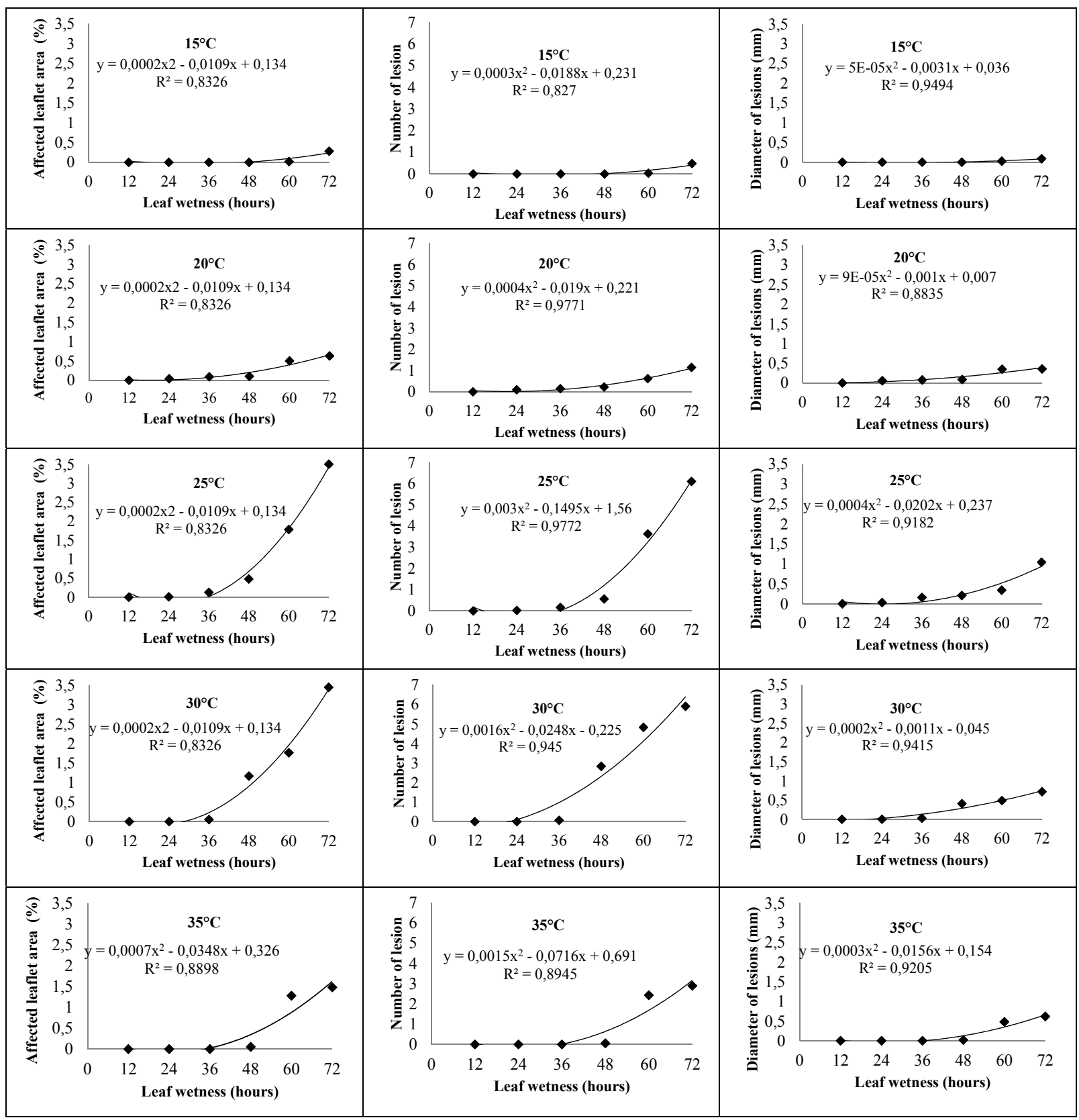


Here, we show that temperature and the duration of leaf wetness affect the intensity of frogeye leaf spot caused by $C$. sojina, with an optimum temperature for infection of $27.3^{\circ} \mathrm{C}$. Similarly, previous work indicated that $C$. sojina mycelial growth was maximized at $25^{\circ} \mathrm{C}$, and limited at temperatures higher than $32^{\circ} \mathrm{C}$. Infection and symptom development are favored by warm $\left(25-30^{\circ} \mathrm{C}\right)$ and humid $(>90 \%$ relative humidity) conditions, where sporulation can occur $48 \mathrm{~h}$ after the first symptoms become visible. Conidia can germinate on a leaf surface within an hour of deposition in the presence of water at 25 to $30^{\circ} \mathrm{C}$ with visible lesions developing 8 to 12 days after inoculation (PHILLIPS, 1999).
According to Alves et al. (2007), temperatures above $30^{\circ}$ and below $15^{\circ} \mathrm{C}$ affect the latent and infectious incubation periods of Phakopsora pachyrhizi Syd. \& P. Syd., which often infect soybeans with $C$. sojina. These findings agree with the temperature data reported here for C. sojina.

Regarding leaf wetness duration, Veiga (1973) found that a 48-h wet period can result in infection, much as we observed, although we also found that the highest disease intensity occurs within a 72-h period. Kudo et al. (2011), showed that a 72-h wet period after $C$. sojina inoculation was sufficient to generate enough disease intensity for soybean genotype screening, a result that closely resembled those by Scandiani et al. (2010). Under these conditions, we observed the first symptoms on the eighth day after inoculation.

Figure 3. The effect of period of leaf wetness and temperature on (A) affected leaflet area (\%), (B) number of lesions per leaflet and $(\mathrm{C})$ diameter of lesions per leaflet $(\mathrm{mm})$ of frogeye leaf spot in soybean cultivar Mario 7.0i.

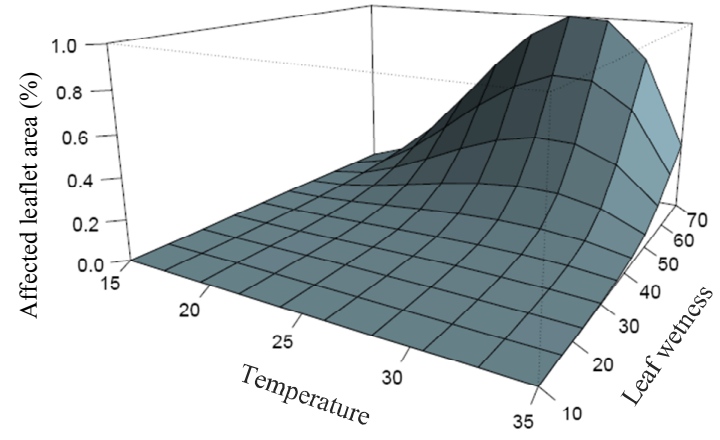

(A)

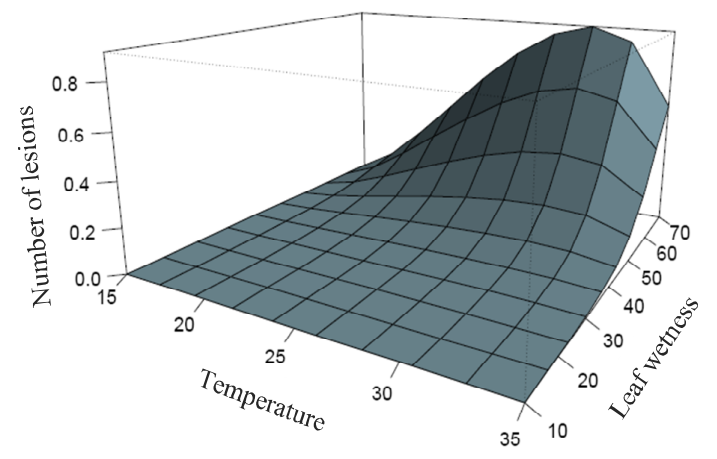

(B)

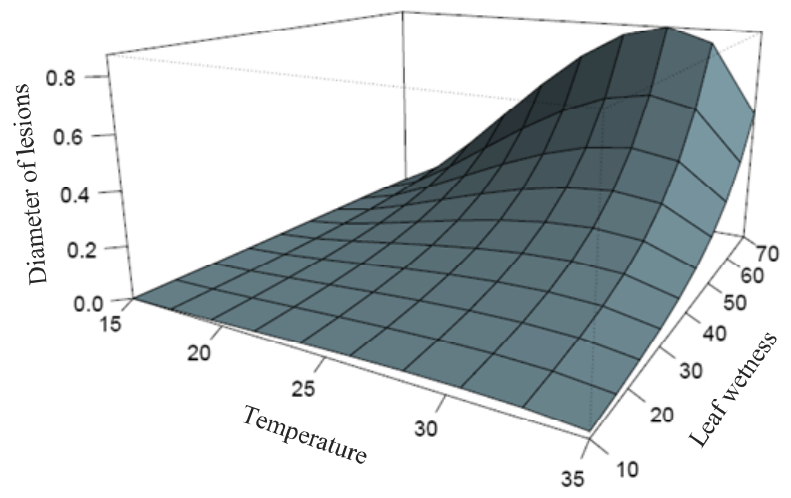

(C) 
Available data have allowed for the development of warning systems for bean angular leaf spot and anthracnose, caused by Pseudocercospora griseola (Sacc.) Crous \& U. Braun and Colletotrichum lindemuthianum (Sacc. \& Magnus) Briosi \& Cavara (REIS; BLUM, 2012). The model uses as input environmental conditions for the infectious process such as continuous leaf wetness duration and mean air temperature during this stage of the pathogenhost cycle. A warning system for $C$. sojina may also be developed from studies such as ours.

\section{Conclusion}

A temperature of $27^{\circ} \mathrm{C}$ and 72 hours of leaf wetness provided the ideal conditions for the infection and development of frogeye leaf spot in soybean plants.

\section{References}

ALFENAS, A. C.; MAFIA, R. G. Métodos em fitopatologia. Viçosa: Editora UFV, 2007. 382 p.

ALVES, M. C.; POZZA, E. A.; FERREIRA, J. B.; ARAÚJO, D. V.; COSTA, J. C. B.; DEUNER, C. C.; MUNIZ, M.F.S.;ZAMBENEDETTI,E.B.; MACHADO, J. C. Intensidade da ferrugem asiática (Phakopsora pachyrhizi) da soja nas cultivares Conquista, Savana e Suprema sob diferentes temperaturas e períodos de molhamento foliar. Summa Phytopathologica, Botucatu, v. 33, n. 3, p. 239-244, 2007.

BEDENDO, I. P.; AMORIM, L. Ambiente e doença. In: REZENDE, J. A.; BERGAMIN FILHO, A.; AMORIM, L. (Ed). Manual de fitopatologia: princípios e conceitos. Piracicaba: Agronômica Ceres, 2011. p. 133-146.

CAMERA, J. N.; DEUNER, C. C.; REIS, E. M.; RANZI, C. Temperature threshold for Cercospora sojina conidium germination under two light regimens. Summa Phytopathologica, Botucatu, v. 39, n. 1, p. 58-61, 2013.

CRUZ, C. D. Impact of foliar diseases on soybean in Ohio: frogeye leaf spot and septoria Brown spot. 2008. Dissertation (Master in Science) - School of Agriculture. The Ohio State University, United States, Ohio.
DEL PONTE, E. M.; GODOY, C. V.; LI, X.; YANG, X. B. Predicting severity of Asian Soybean rust epidemics with empirical rainfall models. Phytopathology, Brasília, v. 96, n. 7, p. 797-803, 2006.

DISTÉFANO, S. G.; LENZI, L.; GADBÁN, L. C.; FUENTES, F. Evaluación de cultivares de soja frente a "mancha ojo de rana" (Cercospora sojina Hara). Córdoba: INTA, 2009. 8 p. Disponível em: <http://www. inta.gov.ar/mjuarez/info/documentos/soja/morsoja10res. $\mathrm{htm}>$. Acesso em: 23 jan. 2011.

HINE, R. B.; ARAGAKI, M. Influence of soil temperature on a crown rot disease of parsley caused by Phytophthora parasitic. Phytopathology, Brasília, v. 53, n. 5, p. 11131114, 1963.

KOENNING, S. R.; WRATHER, J. A. Suppression of soybean yield potential in the continental United States by plant diseases from 2006 to 2009. Plant Health Progress, Ohio, v. 55, n. 2, p. 111-118, 2010. Available at: $<$ http://www.ces.ncsu.edu/wpcontent/uploads/2013/05/ yield20062009loss.pdf $>$. Accessed at: 13 nov. 2011.

KUDO,A. S.; BLUM, L. E. B.; LIMA, M. A. Aerobiologia de Cercospora kikuchii. Ciência Rural, Santa Maria, v. 41, n. 10, p. 1682-1688, 2011.

MIAN, M. A.; MISSAOUI, A. M.; WALKER, D. R.; PHILLIPS, D. V.; BOERMA, H. R. Frogeye leaf spot of soybean: A review and proposed race designations for isolates of Cercospora sojina Hara. Crop Science, Madison, v. 48, n. x, p. 14-24, 2008.

MIAN. R.; BOND, J.; JOOBEUR, T.; MENGISTU, A.; WIEBOLD, W.; SHANNON, G.; WRATHER, A. Identification of soybean genotypes resistant to Cercospora sojina by field screening and molecular markers. Plant Disease, Saint Paul, v. 93, n. 2, p. 408411, 2009.

PHILLIPS, O. V. Frogeye leaf spot. In: HARTMAN, G. L.; SINCLAIR, J. B.; RUPE, J. C. Compendium of soybean diseases. Saint Paul: APS Press, 1999. p. 20-21.

REIS, E. M.; BLUM, M. M. C. Weather-based warning systems for bean angular leaf spot and anthracnose. Summa Phytopathologica, Botucatu, v. 38, n. 3, p. 228231, 2012.

REIS, E. M.; BRESOLIN, A. C. R. Sistemas de previsão de doenças de plantas. In: REIS, E. M. Previsão de doenças de plantas. Passo Fundo: Editora UPF, 2004. p. 155-287.

REIS, E. M.; WORDELL FILHO, J. A. Previsão de doenças de plantas. In: REIS, E. M. (Org.). Previsão de doenças de plantas. Passo Fundo: Editora UPF, 2004. p. 65-99. 
SCANDIANI, M. M.; FERRARI, B.; FORMENTO, N.; LUQUE, A.;CARMONA, M.; TARTABINI, M.; FERRI, M. Evaluación de la resistencia y susceptibilidad de genotipos de soja (Glycine max) a la mancha ojo de rana (Cercospora sojina). Revista Análisis de Semillas, Mar del Plata, v. 4, n. 14, p. 67-72, 2010.

STATSOFT, INC. STATISTICA (Data Analysis Software System). Version 6. Tulsa: Oklahoma, 2001.

SUTTON, J. C.; GILlESPIE, T. J.; HILDBRAND, P. Monitoring weathear factores in relation to plant disease. Plant Disease, Saint Paul, v. 68, n. 1, p. 78-84, 1984.
VEIGA, P. Cercospora sojina Hara: obtenção de inóculo, inoculação e avaliação da resistência em soja [Glycine max (L.) Merr. 1973. Dissertação (Mestrado em Agronomia) - Departamento de Agricultura. Escola Superior de Agricultura Luiz de Queiroz, Piracicaba.

YORINORI, J. T.; KLINGELFUSS, L. H. Novas raças de Cercospora sojina em soja. Fitopatologia Brasileira, Brasília, v. 24, n. 4, p. 509-512, 2000. 